\title{
Special issue: Exploring global and transnational governance of climate change adaptation
}

\author{
Åsa Persson ${ }^{1,2} \cdot$ Adis Dzebo $^{1,3}$
}

Accepted: 23 May 2019 / Published online: 4 June 2019

(c) The Author(s) 2019

$\begin{array}{ll}\text { Abbreviations } \\ \text { 100RC } & \text { 100 Resilient Cities } \\ \text { ACTO } & \text { Amazon Cooperation Treaty Organization } \\ \text { GCAA } & \text { Global Climate Action Agenda } \\ \text { GEF } & \text { Global Environment Facility } \\ \text { GPG } & \text { Global public good } \\ \text { IGO } & \text { Intergovernmental organization } \\ \text { IPCC } & \text { Intergovernmental Panel on Climate Change } \\ \text { IR } & \text { International relations } \\ \text { NAP } & \text { National Adaptation Plan } \\ \text { NDC } & \text { Nationally Determined Contribution } \\ \text { NGO } & \text { Non-governmental organization } \\ \text { TCFD } & \text { Task Force on Climate-related Financial Disclosures } \\ \text { TMN } & \text { Transnational municipal network } \\ \text { UNFCCC } & \text { United Nations Framework Convention on Climate Change }\end{array}$

\section{Introduction}

In post-Paris climate governance, the old mantra that 'mitigation is global; adaptation is local' (see Burton 2011, p. 481) is questioned with increased urgency. A highly localized, place-based approach to accelerating adaptation action seems insufficient. This raises the question: is more global and transnational governance adaptation required, and is it emerging? It is the aim of this Special Issue to provide conceptual approaches and empirical research to respond to these questions and to stimulate a broader academic debate.

Adaptation as an inevitable response to climate change became all the more clear with the evidence presented in the IPCC Special Report on Global Warming of $1.5^{\circ} \mathrm{C}$. Compared with the previous IPCC Assessment Report in 2014, the level of risk associated with

Åsa Persson

asa.persson@sei.org

1 Stockholm Environment Institute, Box 24218, 10451 Stockholm, Sweden

2 Department of Thematic Studies, Linköping University, 58183 Linköping, Sweden

3 Copernicus Institute of Sustainable Development, Utrecht University, Princetonlaan 8a, 3584 CB Utrecht, The Netherlands 
a $2{ }^{\circ} \mathrm{C}$ warming had increased for four out of five 'reasons for concern' (Hoegh-Guldberg et al. 2018). Yet, limits to adaptive capacity are identified already at $1.5{ }^{\circ} \mathrm{C}$ warming and become more pronounced with higher levels of warming. Overall, adaptation efforts worldwide need to accelerate and deepen, and international cooperation is found to be a 'critical enabler' (IPCC 2018, p. 25).

As part of the general adaptation effort, an increasing number of voices are arguing that greater attention is needed to understand and assess transboundary, regional and global climate impacts, or 'borderless climate risks' (see, for example, Khan 2013; Magnan and Ribera 2016; Challinor et al. 2017). Known transboundary resource problems can intensify with climate change, such as water scarcity and quality in shared river basins. Novel and uncertain global systemic risks, induced by climate change, may cascade through the international system, such as food insecurity and price shocks; population displacement and migration; shifts in fish stocks through changing species range; and disruption in global supply chains through climate risk to critical chokepoints. Evidence suggests that vulnerability to these kinds of risk may well be high in places that are also vulnerable to direct and local climate impacts (Hedlund et al. 2018), which could mean further inequality in how costs and benefits of climate change are distributed across the world.

A more 'global' conception of climate change adaptation is also articulated in international climate governance. The 2015 Paris Agreement explicitly defined adaptation as 'a global challenge faced by all with local, sub-national, national, regional and international dimensions' (Art. 7.2). The Paris Agreement also filled a gap in the UN Framework Convention on Climate Change (UNFCCC) in terms of goals on adaptation, by establishing 'the global goal on adaptation of enhancing adaptive capacity, strengthening resilience and reducing vulnerability to climate change, with a view to contributing to sustainable development and ensuring an adequate adaptation response in the context of the temperature goal referred to in Article 2' (Art. 7.1). Beyond stating that progress on this global goal is to be reviewed as part of the global stock-take (Art 7.14), there are, however, no details provided on its implementation, in terms of obligations to take action, reporting responsibilities, indicators and metrics, and their aggregation. In this sense, a structure has been set in place for global adaptation governance, but it needs to be filled with meaningful functions and purpose.

Looking beyond the UNFCCC intergovernmental regime, a broader set of actors see the need for adaptation governance at levels beyond the local and national. Non-governmental organizations (NGOs), business, cities, academia and intergovernmental organizations (IGOs) are mobilizing in transnational adaptation initiatives, many of which are orchestrated under the Global Climate Action Agenda (GCAA). These initiatives are diverse in terms of goals and functions, but a common feature is that they seek to transnationally govern and thus secure benefits beyond the local level through, e.g. capacity building, knowledge sharing and standard setting.

Given the multi-sectoral and nebulous character of climate change adaptation as a policy concept (Lesnikowski et al. 2016a, b), the notion of 'global and transnational adaptation governance' can become an impossibly broad phenomenon to study. Where does it begin and where does it end in relation to other governance domains and policy concepts? For example, the notion of 'climate security' is being promoted in a range of international institutions, such as the UN Security Council. 'Climate resilience' is a term frequently used in the business sector, in development aid and in the transnational governance sphere, while reduction of 'physical risk' from climate change is one of the objectives of the finance sector initiative Task Force on Climate-related Financial Disclosures (TCFD). Furthermore, adaptation is no longer governed only under the UNFCCC regime, but is also 
a more integral part of, for example, the UN Sustainable Development Goals and the Sendai Framework for Disaster Risk Reduction.

We recognize the inherent conceptual ambiguity and the difficulties in drawing distinct boundaries around the adaptation governance domain. However, for the reasons stated above-problem urgency, uncertain and novel cross-boundary risks and emerging de facto governance attempts-it is nevertheless highly timely and justified to systematically examine global and transnational adaptation governance as an object of study. As stated above, the aim of this Special Issue is to provide conceptual approaches and empirical research to better understand the need for, forms of and effectiveness of global and transnational adaptation governance. Our aim is also to, based on the articles in this Special Issue, contribute to the policy agenda by proposing a simple typology for understanding adaptation as a 'global challenge', as defined in the Paris Agreement, and identify future research needs.

Drawing on expertise from political science, economics and law, we present six articles. In brief, Benzie and Persson (2019) trace the traditional territorial framing and national and local scaling of adaptation governance to a particular epistemic community and international norm, and look at governance options for considering borderless climate risks which are now contesting the traditional framing and scaling. Roggero, Kähler and Hagen (2019) offer a conceptual discussion of the problem structure of adaptation in cases where it has cross-boundary spillovers, and illustrate their reasoning with the case of climate change-induced eutrophication of the Baltic Sea. Also focusing on regional governance of water resources, Tigre (2019) explains the untapped potential for building an effective regional adaptation strategy among states in the Amazon region, in order to provide climate resilience as a regional public good. Expanding the analysis from cooperation between state actors only, we then present three articles that empirically analyse transnational adaptation governance. Chan and Wamling (2019) evaluate the effectiveness of 100 transnational adaptation actions and discuss how effectively they have been orchestrated by the Global Climate Action Agenda. Dzebo (2019) assesses 40 transnational adaptation initiatives and seek to identify key success factors. Finally, Papin (2019) provides an in-depth case study of one initiative, the 100 Resilient Cities, and analyses in particular the extent to which this transnational municipal network has been innovative in governance.

This editorial continues with a brief review of key knowledge gaps, in order to lay out important and unanswered research questions for this Special Issue. The subsequent sections synthesize the conclusions of the individual articles in relation to these research questions. Finally, we propose a typology of adaptation as a global challenge to inform the policy agenda and conclude by identifying future research needs.

\section{Addressing key knowledge gaps}

Looking at the academic literature on global climate governance, it is characterized by a strong bias towards theorizing and studying mitigation rather than adaptation (see, for example, Keohane and Victor 2011; Abbott 2012; Pattberg and Stripple 2008; Jordan et al. 2015). This could be explained by the greater policy attention to mitigation in the early days of the UNFCCC regime (Schipper 2006; Pielke et al. 2007). Since adaptation started rising on the global agenda (Khan and Roberts 2013; Gupta 2014), with the Bali Roadmap as a defining moment for putting adaptation on par with mitigation, the interest in analysing international governance of adaptation has increased. However, this research has typically focused on analysing and discussing international equity aspects of adaptation 
and the responsibilities and means for providing financial support to vulnerable developing countries (Pickering et al. 2017; Persson et al. 2009; Ciplet et al. 2015; Moore 2012; Grasso 2010). The issue of climate adaptation finance is obviously an important issue, with both equity and technical dimensions, but in this Special Issue we are interested in international cooperation and global governance around adaptation more broadly; in terms of substantive and procedural commitments of actors to doing adaptation (in addition to funding adaptation). As neatly summarized by Magnan and Ribera (2016, p. 1281), 'a more comprehensive framework for global adaptation can help answer a crucial question that parallels the one on global mitigation: Are we as humankind on track to adapt to climate change?'

As alluded to above, the Paris Agreement constituted an important milestone for adaptation, through the goal and other provisions that can "catalyse societal momentum around adaptation through a broader discourse about climate change and human well-being, cooperation between state and non-state actors, national agenda setting, and the creation of stronger reporting and evaluation mechanisms' (Lesnikowski et al. 2016a, b, pp. 4-5). In the lead-up to and in the aftermath of the Paris Agreement, we now identify a growing scholarship on global and transnational adaptation governance. A pioneering and comprehensive attempt has been made by Khan $(2013,2016)$ to outline a new 'binding regime' for climate adaptation, based on the identified need to redefine the problem structure of climate adaptation. He challenges the conventional definition of adaptation as a mainly local private or public good (Barrett 2008) and argues it also has properties of a global public good (GPG) in some circumstances. He thus proposes that adaptation as a GPG should become an accepted norm underlying institutional design. Another quickly growing literature that implicitly or explicitly address problem structure is that on borderless climate risk (see above and also Moser and Finzi Hart 2015; Challinor et al. 2017; Hedlund et al. 2018), but it has so far been sparse on governance implications. A welcome addition is a recent account by (Banda 2018; see also Gupta et al. 2007), which systematically identifies a multi-level governance model for adaptation with transboundary dimensions, with the aim to optimize efforts and avoid legal over-reach.

Engaging less in problem structure but nevertheless concluding there is a need for more concerted global adaptation governance, Biermann (2014; Biermann and Boas 2010) looks at relevant domains (e.g. migration, health, energy) and international governance architecture overall. He proposes that a 'horizontal' norm of adaptiveness needs to be institutionalized across global governance domains for an effective response. Taking a more evaluative perspective and a functional approach, Hall and Persson (2017) analyse the degree of legalization of existing governance of adaptation under the UNFCCC and conclude it is currently low in both obligation and precision. Broadening the scope to adaptation governance by non-state actors, the literature on transnational governance has thus far been poor at studying adaptation governance initiatives in comparison with mitigation initiatives (Bulkeley et al. 2014; Jordan et al. 2015).

Against this background, this Special Issue sets out to address some specific knowledge gaps in the field of global and transnational adaptation governance. First, as a clarification, we understand global governance here as the entirety of governance efforts, put forward in a 'multilevel system in which local, national, regional and global political processes are inseparably linked' (Dingwerth and Pattberg 2006, p. 192). It thus does not exclusively refer to the international level (by international governance, we refer to cooperation between states and intergovernmental organizations). Transnational governance is one form of global governance, which refers to joint efforts 'between state and non-state actors as they interact across state borders' (Bulkeley et al. 2014, p. 5). Second, we set the 
following joint and broad research questions for the Special Issue articles and address them below:

1. What scales have dominated the framing and subsequent governance of adaptation, and why?

2. What is the problem structure of adaptation? Under what conditions can adaptation be considered to provide a regional or global public good, and what are the governance implications?

3. What kind of transnational governance of adaptation is emerging, and to what extent is it effective and innovative?

\subsection{Scalar framing of adaptation governance}

Starting with a more historical review, Benzie and Persson note the mismatch between the quickly growing interest in transboundary, teleconnected and borderless climate risk and the traditional scale and framing of adaptation in governance. Borderless climate risks are defined as 'any climate risk that crosses national borders in its transmission, whether in a transboundary or teleconnected way'. Such risks do not fit easily with current adaptation governance, the vast majority of which is undertaken at national and sub-national level, through, for example, national and local adaptation plans and strategies. To explain why this framing and scaling have persisted for so long, the authors draw on constructivist perspectives in international relations (IR). They find that the early epistemic community around adaptation was strongly dominated by environmental sciences, which had a natural tendency to focus on direct and local impacts, and by case study research designs, which reinforced the significance of place specificity. This served to support and reproduce the norm that was institutionalized under the UNFCCC in the early days; that adaptation was a local and national responsibility, not international. Although the norm of international responsibility to fund adaptation in vulnerable developing countries has coexisted, the appropriate scale and level to govern and to 'do' adaptation has been seen as the national or sub-national (see also Roggero et al.). Recently, however, the epistemic community is becoming more diverse and fragmented, with more expertise from risk studies, supply chain management, migration, etc., being applied, and the norm is starting to be questioned, e.g. with more multilateral funds funding regional adaptation projects.

\subsection{Problem structure and governance implications}

Identifying some climate risks to have a 'borderless' problem structure, Benzie and Persson conclude their paper by mapping out different governance responses: national and bilateral; transnational; and international and regional. They elaborate on Khan's (2016) discussion of how different IR perspectives prescribe different responses, not all of which involve more global or transnational adaptation governance. Overall, they call for more engagement by IR scholars in studying adaptation to do more systematic evaluation of these high-level options.

Drawing on economic theory, Roggero et al. respond to the question on problem structure by systematically comparing adaptation with mitigation and testing their argument on the case of adaptation to climate change-induced eutrophication of the Baltic Sea (a regional sea surrounded by nine countries). They conclude that when there are 'crossboundary adaptation spillovers', i.e. externalities that occur if adaptation measures by one 
country affect other countries, a similar problem structure applies to adaptation and mitigation. This further means that some measures to enhance regional/international cooperation relevant in the mitigation context can also be considered for adaptation: multiple and small coalition structures can be superior to a single large but shallow coalition, and side payments, issue linkages and trade sanctions can be introduced to incentivize cooperation on adaptation. In summary, they conclude that the problem structure of adaptation is likely often one of an impure public good, in that local co-benefits can be captured by states. Furthermore, they acknowledge that in practice international and transnational adaptation governance is often likely to have other justification than a rationalist response to problem structure. Overall, their account proposes a narrower understanding of adaptation as a public good than Khan's, which draw on Kaul et al.'s (1999) expansive definition of GPGs as pertaining also to human-made global commons (e.g. knowledge, global networks) and policy outcomes and conditions (e.g. security, peace).

Tigre complements this conceptual work by an empirical study of (the lack of) regional cooperation on climate adaptation in the Amazon region. A regional strategy could provide water security as a regional public good. Yet, such a strategy has not yet materialized, although the Amazon Cooperation Treaty Organization (ACTO) could be the natural home and despite substantial analytical and policy preparatory work through a Global Environment Facility (GEF) project. Instead, fragmented adaptation priorities are voiced in Nationally Determined Contributions (NDCs), National Adaptation Plans (NAPs) and other areas of regional cooperation, which together fail to provide a comprehensive and coordinated regional adaptation strategy. Pointing to Central America as a similar example, regional adaptation has successfully been secured there and the author thus argues that a regional strategy for the Amazon region should be feasible.

\subsection{The effectiveness and innovation of emerging transnational adaptation governance}

Having noted both constraints and untapped potential of international and regional governance of adaptation, the following three papers focus on transnational adaptation governance (Chan and Amling; Dzebo; Papin). They share the perception that transnationalization could be the next iteration of the historical development of adaptation in climate governance. All three papers help connect adaptation action to theory on transnational governance and empirically analyse the effectiveness and level of innovation in current transnational adaptation governance.

Chan and Amling, and Dzebo both start from a functionalist assumption that transnational actors should fill gaps left by states and international organizations in governing and ensuring adaptation action, but also note limitations of such assumptions (e.g. strategic interests motivate non-state actors to participate). Chan and Amling take a highlevel view and consider the issue of orchestration of transnational actions and whether the orchestration process has been effective in addressing functional governance deficits, left by states and international organizations. A dataset of 100 initiatives, focusing on mitigation and/or adaptation, is used as basis for evaluating effectiveness. Dzebo, on the other hand, focuses more specifically on 40 adaptation-oriented initiatives and uses an analytical framework to seek explanations of varying performance. Together, these two papers significantly advance knowledge about transnational climate governance in general and transnational adaptation governance in particular, and their datasets will be useful for further studies, including comparison over time. 
The key results that stand out are that mitigation actions still dominate the GCAA and have been highlighted more, partly because they have been more successful and orchestrators wanted to tell a positive story (Chan and Amling). Adaptation actions have performed worse on output effectiveness than mitigation actions, because they needed more time to mature and were often targeting developing countries and thus needed more support. A geographical imbalance persists, in terms of overrepresentation of North-based participants. While Dzebo presents a more positive assessment of the effectiveness of outputs (less so of outcomes), both papers find that transnational adaptation initiatives are typically led by public actors rather than private actors and that the governance functions typically exercised are institutional capacity building and knowledge dissemination (as opposed to standard setting and on-the-ground action). Seeking to explain effective performance, Dzebo finds that - perhaps less expected in view of the voluntary involvement of actors in transnational adaptation initiatives - initiatives based on 'hard' functions (i.e. standard setting and service provision as opposed to knowledge transfer) and binding rules for partners were found to be more effective. For the future, Chan and Amling propose that the GCAA should build more linkages to national and regional levels, since the focus is now shifting to implementing NDCs, many of which are developed by low- and middle-income countries who prioritize adaptation.

A complementary in-depth case study of one transnational adaptation initiative, the 100 Resilience Cities (100RC), is offered by Papin. Her research is specifically interested in how innovative transnational municipal networks (TMNs) are in climate governance. Defining innovation as 'a new arrangement of existing elements designed to fulfil one or several adaptation goals, before it is diffused to other actors or structures', she develops a typology of governance functions for analysing particular instruments used by the 100RC and the extent to which they are innovative. She finds that original instruments were indeed created, including the membership criteria of the network, a platform for accessing pro bono resources and a mandatory chief resilience office position. Further, there was an unexpected reliance on 'hard' and direct tools, somewhat in contrast to the predominantly soft governance functions identified by the other two articles.

Overall, these three studies show that there is significant interest in transnational approaches to adaptation, but that they need more time to mature to become effective and to diffuse innovative features. All three studies also explicitly or implicitly point to the role of sustainable funding for initiatives and the role of large and stable host or lead institutions.

\section{Future prospects of global and transnational adaptation governance: contributing to policy and research agendas}

Overall, with the more severe future climate impacts described in the recent IPCC Special Report (see above), we can expect climate change adaptation to become more of a 'high-politics' issue. As noted, there is a growing interest from the security governance domain and the capital-rich finance sector. This means that adaptation governance and practice may increasingly shift from its earlier 'depoliticized' and 'technocratic' incarnations (Schultz and Siriwardane 2015; Remling 2018). While it is still unclear where critical adaptation-related decisions will be taken, it seems reasonable to assume that stakes in adaptation governance will increase. 
At the same time, the articles of this Special Issue, and the broader literature on global and transnational adaptation governance, seem to agree that a diversified and multi-level governance approach is needed. It is not about fully 'scaling up' adaptation governance to supranational institutions nor fully 'scaling down' to local and community level (Gupta et al. 2007; Banda 2018) — or indeed 'scaling away' from planned adaptation by public actors to purely autonomous adaptation by individuals and markets. However, with the Paris Agreement provisions on adaptation, we can expect and work towards more theoretically informed, evidence-based and coordinated governance from the international level and more orchestration of transnational adaptation initiatives.

As a first step, we can use the articles and literature referred to here to start filling the adaptation structures of the Paris Agreement with meaningful content. More specifically, we can propose the following tripartite typology for defining how and why adaptation constitutes a 'global challenge' (Art. 7.2) (Table 1).

We call upon the research community to contribute, in particular, to the design of the global stock-take as it applies to the global goal on adaptation: what should be reported, why, by whom and how (UNEP 2017)? How can knowledge and resources be pooled, to enable wider learning and capacity building? How can Parties and other actors track adaptation activities in a way that maximize learning and implementation effectiveness?

Finally, we summarize here the needs for future research as identified collectively by the articles in this Special Issue. First, more empirical research of problem structure of borderless risk and cross-boundary adaptation spillovers is needed. A starting point could be regional adaptation projects as funded by multilateral climate funds. Further, tentative lists of adaptation-related GPGs could be firmed up through more rigorous analysis and classification. As noted by Roggero et al., more translation of economic models for mitigation to adaptation is needed. Second, evaluations of the effectiveness of global and transnational adaptation governance need to address outcomes and impact to a greater extent, to

Table 1 Typology for defining adaptation as a global challenge

\begin{tabular}{lc}
\hline Adaptation as a... & Nature of the 'global challenge' \\
\hline $\begin{array}{l}\text { Response to global and borderless climate impact } \\
\text { and risks }\end{array}$ & $\begin{array}{c}\text { The global challenge here refers to the scale and } \\
\text { nature of climate impacts, whether global, regional, } \\
\text { transboundary or teleconnected. Internationally or } \\
\text { transnationally coordinated cooperation on adapta- } \\
\text { tion is not essential, but can be part of a robust, } \\
\text { multi-level governance arrangement }\end{array}$ \\
$\begin{array}{ll}\text { Global or regional public good, through cross- } \\
\text { boundary spillovers }\end{array}$ & $\begin{array}{l}\text { actors cooperate to provide the public good and to } \\
\text { avoid free-riding or sub-optimal outcomes. Inter- } \\
\text { national governance can design rules for who and } \\
\text { how to provide the public good, and transnational } \\
\text { initiatives can be part of the incentivizing action }\end{array}$ \\
$\begin{array}{l}\text { International and transnational governance initia- } \\
\text { tives need not be rationalist responses to problem } \\
\text { tion }\end{array}$ & $\begin{array}{l}\text { structure, either in terms of the scale of the impact } \\
\text { or the public good properties of the adaptation } \\
\text { action itself (as above). They can be expressions } \\
\text { of interest from actors at the international level in } \\
\text { learning from others, in the context of the need for } \\
\text { urgent action }\end{array}$ \\
\end{tabular}


facilitate learning on design. Also, to what extent are initiatives complementary or conflicting, and resulting in undesired fragmentation? Third, several articles identify a need for more studies of the interests, power and political economy of adaptation governance initiatives. To what extent do they create new opportunities and power relationships and to what extent are they reproducing existing ones?

Acknowledgements The articles in this special issue were originally presented at the research workshop The emerging complexity of climate adaptation governance in a globalising world, Stockholm 22-24 May 2017 which was funded by the Swedish Research Council Formas (Grants No. 2015-344 'Transnational adaptation governance' and No. 211-2012-1842 'Global governance of adaptation'). We are thankful to all participants at the workshop who discussed these and other papers. We are particularly grateful to Richard Klein, Magnus Benzie and Kevin Adams who contributed to the development of a typology for adaptation as a global challenge.

Open Access This article is distributed under the terms of the Creative Commons Attribution 4.0 International License (http://creativecommons.org/licenses/by/4.0/), which permits unrestricted use, distribution, and reproduction in any medium, provided you give appropriate credit to the original author(s) and the source, provide a link to the Creative Commons license, and indicate if changes were made.

\section{References}

Abbott, K. W. (2012). The transnational regime complex for climate change. Environment and Planning C: Government and Policy, 30(4), 571-590. https://doi.org/10.1068/c11127.

Banda, M. L. (2018). Global adaptation law: Optimizing legal design for multi-level public goods after the Paris Agreement. Vanderbilt Journal of Transnational Law, 51(4), 997-1026.

Barrett, S. (2008). Climate treaties and the imperative of enforcement. Oxford Review of Economic Policy, 24(2), 239-258. https://doi.org/10.1093/oxrep/grn015.

Benzie, M., \& Persson, A. (2019). Governing borderless climate risks: Moving beyond the territorial framing of adaptation. International Environmental Agreements: Politics, Law and Economics. https://doi. org/10.1007/s10784-019-09441-y.

Biermann, F. (2014). Earth system governance: World politics in the anthropocene. Cambridge: MIT Press.

Biermann, F., \& Boas, I. (2010). Global adaptation governance: Setting the stage. In F. Biermann, P. Pattberg, \& F. Zelli (Eds.), Global climate governance beyond 2012: Architecture, agency and adaptation. New York: Cambridge University Press.

Bulkeley, H., Andonova, L., Betsill, M., Compagnon, D., Hale, T., Hoffman, M., et al. (2014). Transnational climate change governance. New York: Cambridge University Press.

Burton, I. (2011). Adaptation to climate change: Context, status, and prospects. In J. D. Ford \& L. Berrang-Ford (Eds.), Climate change adaptation in developed nations (Vol. 42, pp. 477-483). Dordrecht: Springer. https ://doi.org/10.1007/978-94-007-0567-8_35.

Challinor, A. J., Adger, W. N., \& Benton, T. G. (2017). Climate risks across borders and scales. Nature Climate Change, 7(9), 621-623. https://doi.org/10.1038/nclimate3380.

Chan, S., \& Amling, W. (2019). Does orchestration in the Global Climate Action Agenda effectively prioritize and mobilize transnational climate adaptation action? International Environmental Agreements: Politics, Law and Economics. https://doi.org/10.1007/s10784-019-09444-9.

Ciplet, D., Roberts, J. T., \& Khan, M. R. (2015). Power in a warming world. Cambridge: MIT Press. https:// mitpress.mit.edu/books/power-warming-world.

Dingwerth, K., \& Pattberg, P. (2006). Global governance as a perspective on world politics. Global Governance, 12(2), 185-203.

Dzebo, A. (2019). Effective governance of transnational adaptation initiatives. International Environmental Agreements: Politics, Law and Economics. https://doi.org/10.1007/s10784-019-09445-8.

Grasso, M. (2010). An ethical approach to climate adaptation finance. Global Environmental Change, 20(1), 74-81. https://doi.org/10.1016/j.gloenvcha.2009.10.006.

Gupta, J. (2014). The history of global climate governance. Cambridge: Cambridge University Press.

Gupta, J., van der Leeuw, K., \& de Moel, H. (2007). Climate change: A 'glocal' problem requiring 'glocal' action. Environmental Sciences, 4(3), 139-148. https://doi.org/10.1080/15693430701742677.

Hall, N., \& Persson, Å. (2017). Global climate adaptation governance: Why is it not legally binding? European Journal of International Relations. https://doi.org/10.1177/1354066117725157. 
Hedlund, J., Fick, S., Carlsen, H., \& Benzie, M. (2018). Quantifying transnational climate impact exposure: New perspectives on the global distribution of climate Risk. Global Environmental Change, 52(September), 75-85. https://doi.org/10.1016/j.gloenvcha.2018.04.006.

Hoegh-Guldberg, O., Jacob, D., Taylor, M., Bindi, M., Brown, S., Camilloni, I., et al. (2018). Impacts of $1.5^{\circ} \mathrm{C}$ of global warming on natural and human systems. In V. Masson-Delmotte, P. Zhai, H.-O. Pörtner, D. Roberts, J. Skea, P. R. Shukla, A. Pirani, et al. (Eds.), Global warming of $1.5^{\circ} \mathrm{C}$. An IPCC special report on the impacts of global warming of $1.5^{\circ} \mathrm{C}$ above pre-industrial levels and related global greenhouse gas emission pathways, in the context of strengthening the global response to the threat of climate change, sustainable development, and efforts to eradicate poverty (Vol. 138). Geneva: IPCC.

IPCC. (2018). Summary for policymakers. In V. Masson-Delmotte, P. Zhai, O. Portner, D. Roberts, J. Skea, P. R. Shukla, A. Pirani, et al. (Eds.), Global warming of $1.5^{\circ} \mathrm{C}$. An IPCC special report on the impacts of global warming of $1.5^{\circ} \mathrm{C}$ above pre-industrial levels and related global greenhouse gas emission pathways, in the context of strengthening the global response to the threat of climate change, sustainable development, and efforts to eradicate poverty. Geneva: World Meteorological Organization.

Jordan, A. J., Huitema, D., Hildén, M., van Asselt, H., Rayner, T. J., Schoenefeld, J. J., et al. (2015). Emergence of polycentric climate governance and its future prospects. Nature Climate Change, 5(11), 977-982. https ://doi.org/10.1038/nclimate2725.

Kaul, I., Grunberg, I., \& Stern, M. A. (Eds.). (1999). Global public goods: international cooperation in the 21st century. New York: Oxford University Press.

Keohane, R. O., \& Victor, D. (2011). The regime complex for climate change. Perspectives on Politics, 9(01), 7-23. https://doi.org/10.1017/S1537592710004068.

Khan, M. R. (2013). Toward a binding climate change adaptation regime: A proposed framework (1st ed.). New York: Routledge.

Khan, M. (2016). Climate change, adaptation and international relations theory. In Ed Atkins \& Gustavo SosaNunez (Eds.), Environment, climate change and international relations (pp. 14-28). Bristol: E-International Relations Publishing.

Khan, M. R., \& Roberts, J. T. (2013). Adaptation and international climate policy. Wiley Interdisciplinary Reviews: Climate Change, 4(3), 171-189. https://doi.org/10.1002/wcc.212.

Lesnikowski, A., Ford, J., Biesbroek, R., Berrang-Ford, L., \& Heymann, S. J. (2016a). National-level progress on adaptation. Nature Climate Change, 6(3), 261-264. https://doi.org/10.1038/nclimate2863.

Lesnikowski, A., Ford, J., Biesbroek, R., Berrang-Ford, L., Maillet, M., Araos, M., et al. (2016b). What does the Paris agreement mean for adaptation? Climate Policy. https://doi.org/10.1080/14693062.2016.1248889.

Magnan, A. K., \& Ribera, T. (2016). Global adaptation after Paris. Science, 352(6291), 1280-1282. https://doi. org/10.1126/science.aaf5002.

Moore, F. C. (2012). Negotiating adaptation: Norm selection and hybridization in international climate negotiations. Global Environmental Politics, 12(4), 30-48. https://doi.org/10.1162/GLEP_a_00138.

Moser, S. C., \& Finzi Hart, J. (2015). The long arm of climate change: Societal teleconnections and the future of climate change impacts studies. Climatic Change, 129(1-2), 13-26. https://doi.org/10.1007/s1058 4-015-1328-z.

Papin, M. (2019). Transnational municipal networks: Harbingers of innovation for global adaptation governance? International Environmental Agreements: Politics, Law and Economics. https://doi.org/10.1007/ s10784-019-09446-7.

Pattberg, P., \& Stripple, J. (2008). Beyond the public and private divide: Remapping transnational climate governance in the 21st century. International Environmental Agreements: Politics, Law and Economics, 8(4), 367-388. https://doi.org/10.1007/s10784-008-9085-3.

Persson, A., Klein, R. J. T., Kehler Siebert, C., Atteridge, A., Müller, B., Hoffmaister, J., et al. (2009). Adaptation finance under a Copenhagen agreed outcome. Stockholm: Stockholm Environment Institute.

Pickering, J., Betzold, C., \& Skovgaard, J. (2017). Special issue: Managing fragmentation and complexity in the emerging system of international climate finance. International Environmental Agreements: Politics, Law and Economics, 17(1), 1-16. https://doi.org/10.1007/s10784-016-9349-2.

Pielke, R., Prins, G., Rayner, S., \& Sarewitz, D. (2007). Climate change 2007: Lifting the Taboo on adaptation. Nature, 445(7128), 597-598. https://doi.org/10.1038/445597a.

Remling, E. (2018). Depoliticizing adaptation: A critical analysis of EU climate adaptation policy. Environmental Politics, 27(3), 477-497. https://doi.org/10.1080/09644016.2018.1429207.

Roggero, M., Kähler, L., \& Hagen, A. (2019). Strategic cooperation for transnational adaptation: Lessons from the economics of climate change mitigation. International Environmental Agreements: Politics, Law and Economics. https://doi.org/10.1007/s10784-019-09442-x.

Schipper, E. L. F. (2006). Conceptual history of adaptation in the UNFCCC process. Review of European Community \& International Environmental Law, 15(1), 82-92. https://doi.org/10.111 1/j.1467-9388.2006.00501.x. 
Schultz, K., \& Siriwardane, R. (2015). Depoliticised and technocratic? Normativity and the politics of transformative adaptation. Earth System Governance Working Paper No. 33. Lund and Amsterdam: Earth System Governance Project.

Tigre, M. A. (2019). Building a regional adaptation strategy for Amazon countries. International Environmental Agreements: Politics, Law and Economics. https://doi.org/10.1007/s10784-019-09443-w.

UNEP. (2017). The adaptation gap report 2017. Nairobi: United Nations Environment Programme.

Publisher's Note Springer Nature remains neutral with regard to jurisdictional claims in published maps and institutional affiliations. 